\title{
Birds and the October Blizzards in Manitoba
}

\author{
by David Hatch, Oak Lake, Manitoba
}

Having read Frank Brazier's article on the "Big Snow of October" in the December issue of the Blue Jay (XVII:154-5) I decided to describe the effects of the blizzards in this part of Manitoba.

At 1:00 a.m. on October 7, it stanted to snow at Oak Lake. This was the beginning of three storms caused by a chain of low pressure areas moving into the prairies from the Pacific Ocean. A tctal of 31.5 inches of snow fell in three separate snowfalls before the blizzards ended on October 12. A wind which varied between ten and forty miles per hour heaped the snow into eight-foot drifits. Between October 7 and 12 the temperature ranged between about 20 degrees, and 33 degrees Fahrenheit. A good deal of the snow melted, but never enough for us to see the stubible.

At the time of the blizzards, the great majority of the trees were still clothed in their fall robes of golden and brown leaves. The moisture content of the snow was very high and, as a result, branches six inches thick were broken under the strain and crashed to the ground. Miles and miles of fences sagged, and in many cases wires broke and staples pulled from the posts.

It was impassible for hawks to find rodents in the snow-covered fields so they were forced to migrate from this area or to change their diet. Between 11:55 a.m. and 12:27 a.m. on October 8, I saw seventeen buteos flying southeast between 75 and 200 yards high. Later the same day I observed a Red-tailed Hawk eating a small bird not more than forty yards from our house. On October 9, I saw an adult male Marsh Hawk, a Cooper, a Sharp-shinned, and a Sparrow Hawk. Four more buteos were seen on October 11. These were the last I saw until a warm change in the weather, beginning on October 18 , sent in a fresh movement.

About six Myrtle Warblers were seen every day of the storm, with the last one seen on October 17 . One Orange-crowned Warbler was seen on October 12. On October 9, the last
Palm Warbler was seen fluttering from one window to another in an attempit to get into the house.

Millet was scattered in the shelter of a granary and under our kitchen window. To these weed seeds a Mourning Dove was attracted on both October 11 and October 12. On October 10 as many as sixty Slate-colored Juncos fed on the millet. Whenever a large bird such as a Rusty Blackbird came to feed, the Juncos gave ground.

Of all the species, Western Meadowlarks were the hardest hit in my opinion. On October 8 , there were fifteen meadowlarks feeding on the seeds put out for them and by October 17, there were only seven. Three were found dead around the farm buildings and another seven were caught which were too weak to fly. Three of these birds had frozen their legs from sitting in the snow. When chased, they would fly and run over the snow until they were exhausted; then one could catch them. We put them in a granary and opened a window for them to fly in and out if they wanted. To my knowledge one of the birds we put in the granary died. Two that were in a precarious state were brought into the house, where one, after loving care, survived.

I found a Lincoln's Sparrow and two Myrtle Warblers dead. The snow melted enough in our yard for me to find three dead Eared Grebes. They were probably forced to land by the wet snow on the back and wings and of course could not leave the ground.

With the coming of the first blizzard the ducks vacated the Oak Lake marshes and moved south. On the afternoon of October 9, I walked around two of our biggest. marshes and to my surprise there were only about three hundred ducks huddled in a few open holes in the ice. I was able to get within 15 yards of 200 graceful Whistling Swans sitting around the edge and in an open hole in the ice. They were apparently waiting for a break in the weather so that they could continue their southern flight.

Besides the juncos that fed on mil- 
let under our kitchen window, a Clay-colored, a Harris', and two Tree Sparrows were daily visitors. What a wonderful chance to observe birds at close range!

A mild spell in the latiter part of Ootober sent about 300 ducks through here on October 24. Also, on October 24, I saw a Greater Yellowlegis. On
October 21, there was an exhausted Common Snipe wandering among the cattle in our barnyard. How these birds survived the blizzards is a deep mystery to me. Many, of course, did not survive, and it would have been impossible to estimate the number of birds killed by the blizzard in the Oak Lake marshes alone.

\section{Saskatchewan Birds in August, 1959}

\section{As Noted by J. Murray Speirs and Doris H. Speirs, Pickering, Ont.}

August 19 was a cool, overcast day with frequen't thundershowers and a chill wind from the northeast. In the morning we drove east along Manitoba's Highway 19 for nine miles to the spot where we had seen a pair of Northern Three-toed Woodpeckers the night before, where Olive-sided Flycatchers called and a Lincoln's Sparrow sang. In the morning drizzle we did not venture from the car: a big bull moose stared at us from the shadows under the evergreens and a group of Boreal Chickadees uttered their nasal version of che Black-capped Chickadee's call. We left our boreal friends and drove south through Brandon, then west through Virden, reaching the Saskatchewan border at 5.20 p.m. We had hoped to spend the night at Moose Mountain but were advised against trying the road down in the pouring rain. There was a brief flash of sun just before sunset and a Clay-colored Sparrow sang as we turned in at Moosomin.

Next morning, August 20, we drove in to Regina, passing a flock of about 80 Black-billed Magpies between Whitewood and Grenfell and stopping to admire a beautiful pair of Krider's Red-tailed Hawks between Indian Head and Regina. One had a white head and tail and big white wing patches; the other was similar but with a tinge of red on the terminal third of its tail. The call was not so guttural as that of our eastern red-tails. We had our first view of the beautiful new museum in Regina and had lunch with our friends Robert Nero and the Hamerstroms (also arrived early for the A.O.U., from Wisconsin). We decided to head for the Cypress Hills and turned in early again on another stormy night ait Moose Jaw.

Aug. 21 was a seraphic day and we set forth from Moose Jaw in high anticipation. Before we reached Mortlach we stopped to admire a lovely patch of roadside sage, fresh washed by several days of rain, when out burst a flock of six Sharp-tailed Grouse, our first on this western trip. We had hardly started up when a family of Gray Partridge was spotted on the far side of the rcad. Near the salty Lake Chaplin we saw our first Willet for Saskatchewan and 35 Avocets (as Dr. Nero had predicted). The highlight of the morning was Reed Lake. It was full of ducks of at least nine species including a Gadwall with four young. Its shores were lined with Franklin's and Ring-billed Gulls with a good sprinkling of shorebirds including 2 Wilscn's Phalaropes. We stopped to investigate a road kill and found that it was a Short-eared Owl. Another road kill proved to be a porcupine: what do porcupines live on out in the open prairies far from any trees? We arrived at Cypress Hills in mid-afternoon, only to find the available accommodation solidly booked. As it was early we decided to look around, having left our name in case a vacancy should turn up. Black-capped Chickadees were omnipresent as were the rather pale Oregon Juncos and Audubon's Warblers. Red Crossbills flew over, calling "yip, yip" from time to time. In late afternoon a cabin became available and we moved in, lit a fire and opened windows as the cabin appeared to have a striped tenant below the floor. This joint tenancy became more and more dif- 